\title{
21. ORGANIC GEOCHEMISTRY OF SOME CRETACEOUS CLAYSTONES FROM SITE 391, LEG 44, WESTERN NORTH ATLANTIC
}

\author{
G. Deroo, J.P. Herbin, J.R. Roucache, and B. Tissot, Institut Français du Pétrole, \\ Rueil-Malmaison, France \\ and \\ P. Albrecht and M. Dastillung, Institut de Chimie, Université Louis Pasteur, \\ Strasbourg, France
}

\begin{abstract}
The dark Cretaceous claystones recovered from Site 391 in the Blake-Bahama Basin during DSDP Leg 44 are definitely not sapropelitic sediments. Most of their organic matter is thermally immature and derived from a continental source.
\end{abstract}

\section{INTRODUCTION}

We have studied the organic geochemistry of the Cretaceous claystones cored during DSDP Leg 44 in the post-Barremian sediments of the Blake-Bahama Basin to define the type of organic sediments present and to determine whether or not they are sapropelitic shales.

First, we performed a pyrolysis assay to detect hydrocarbons in raw samples and chloroformic extractions which allowed us to characterize the type of organic matter in the sediments. We then studied the remaining insoluble fraction, i.e., the humic compounds and the kerogen fraction in the organic matter to determine whether the organic material is of marine or continental origin. Humic compounds are more common in immature than in mature sediments, whereas the kerogen fraction forms a significant part of both the immature and mature sediments.

\section{SAMPLING}

The eight samples, of $150-200 \mathrm{~g}$ each, from Site 391 (Figure 1) were recovered from the Blake-Bahama Basin halfway between Sites 104 (Blake Outer Ridge) and 101 (Bahama Outer Ridge). Four of them are Upper Cretaceous silty claystones; the others are lower Albian and/or Aptian calcareous claystones (Table 1).

\section{ANALYTICAL METHODS}

The eight samples were freeze-dried and ground in an AUREC pulverizer (grain size $\cong 90 \mu \mathrm{m}$ ). The succession of analytical processes is shown on Figure 2. The organic carbon content was determined with a LECO analyzer. A pyrolysis assay was applied to the raw samples (Espitalie et al., 1977) to rapidly determine source rock and maturation characteristics. (The methods are taken from kerogen experimental studies by Durand and Espitalie, 1973; Espitalie et al., 1973; and Tissot et al., 1974.) Equivalent fractions of ground samples were then extracted with chloroform and fractionated by thin-layer chromatography (Huc et al., 1976). The total humic fraction was extracted from the insoluble part of rock and humic acids were separated

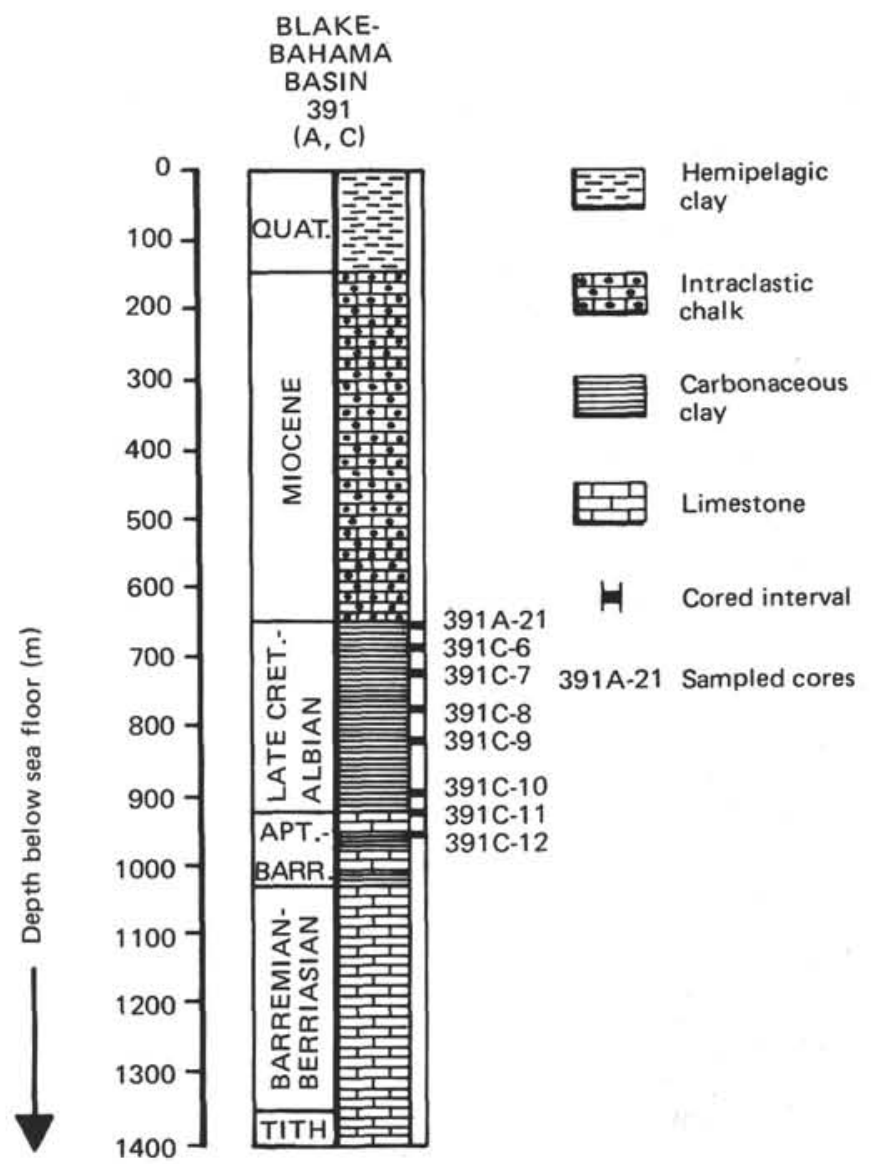

Figure 1. Stratigraphic column of Site 391 showing location of samples.

from fulvic acids (Huc et al., 1978). The related insoluble fraction corresponds to kerogen (Durand et al., 1972; Robin et al, in press). Organic content analysis from total humic compound and from fulvic fraction were performed on a Carmhograph Wosthoff apparatus. Elemental analyses of carbon, hydrogen, oxygen, nitrogen, sulfur, and iron, and the ash content were measured on kerogen and calculated on a mineralfree basis. 
TABLE 1

Sub-Bottom Depths, Lithology, Age, and Carbon Data for Samples Studied From Site 391

\begin{tabular}{|c|c|c|c|c|c|}
\hline \multirow[b]{2}{*}{$\begin{array}{c}\text { Sample } \\
\text { (Interval in cm) }\end{array}$} & \multirow{2}{*}{$\begin{array}{l}\text { Depth } \\
\text { Below } \\
\text { Sea } \\
\text { Floor } \\
(\mathrm{m})\end{array}$} & \multirow{2}{*}{$\begin{array}{l}\text { Lithology } \\
\text { and } \\
\text { Age }\end{array}$} & \multirow[b]{2}{*}{$\% \mathrm{CO}_{3} \mathrm{Ca}$} & \multicolumn{2}{|c|}{$\begin{array}{c}\text { Organic } \\
\text { Carbon } \\
(\%)\end{array}$} \\
\hline & & & & $\begin{array}{c}\text { Before } \mathrm{HCCl}_{3} \\
\text { Extraction }\end{array}$ & $\begin{array}{c}\text { After } \mathrm{HCCl}_{3} \\
\text { Extraction } \\
\end{array}$ \\
\hline \multicolumn{6}{|l|}{ Hole 391A } \\
\hline $21-4,125-130$ & 655 & $\begin{array}{l}\text { Claystone } \\
\text { (Upper Cretaceous) }\end{array}$ & 2 & 0.29 & 0.28 \\
\hline \multicolumn{6}{|l|}{ Hole 391C } \\
\hline $6-3,145-150$ & 690 & $\begin{array}{l}\text { Claystone with } \\
\text { silt stringers } \\
\text { (Upper Cretaceous) }\end{array}$ & 8 & 0.72 & 0.71 \\
\hline $7-2,136-142$ & 730 & $\begin{array}{l}\text { Claystone and } \\
\text { silty claystone } \\
\text { (Upper Cretaceous) }\end{array}$ & 2 & 1.27 & 1.26 \\
\hline $8-2,145-150$ & 785 & $\begin{array}{l}\text { Claystone and } \\
\text { siltstone } \\
\text { (Upper Cretaceous) }\end{array}$ & 2 & 1.12 & 1.11 \\
\hline $9-3,145-150$ & 842 & $\begin{array}{l}\text { Claystone and } \\
\text { marly limestone } \\
\text { (Upper Aptian } \\
\text { Lower Albian) }\end{array}$ & 7 & 1.50 & 1.48 \\
\hline $10-3,145-150$ & 905 & $\begin{array}{l}\text { Silty claystone } \\
\text { with limestone } \\
\text { (Upper Aptian } \\
\text { Lower Albian }\end{array}$ & 32 & 2.72 & 2.69 \\
\hline $11-2,145-150$ & 925 & $\begin{array}{l}\text { Silty calcareous } \\
\text { claystone } \\
\text { (? Upper Aptian) }\end{array}$ & 68 & 0.92 & 0.90 \\
\hline $12-4,120-125$ & 959 & $\begin{array}{l}\text { Calcareous claystone } \\
\text { with limestone } \\
\text { (Aptian) }\end{array}$ & 10 & 2.07 & 1.80 \\
\hline
\end{tabular}

\section{DETAILED RESULTS}

\section{Mineral Carbon (Table 1)}

Two samples, 391C-10-3, 145-150 cm (upper Aptianlower Albian) and 391C-11-2, 145-150 cm (supposed upper Aptian) had a high carbonate content (32\% and $68 \%$ ). All others, either from Upper Cretaceous and upper Aptian-lower Albian or Aptian sediments, had low carbonate contents (less than $10 \%$ ).

\section{Organic Carbon (Table 1)}

The two samples, 391A-21-4, 125-130 cm and 391A6-3, $145-150 \mathrm{~cm}$, from the upper part of the interval had a low content of organic carbon (less than $0.8 \%$ ). The others ranged from 0.92 per cent to 2.72 per cent.

\section{Pyrolysis Assay and Organic Matter Characterization (Table 2)}

The pyrolysis assay method is a rough simulation of the elemental analysis method used upon kerogen (Tissot et al., 1974). The combined oxygen and hydrogen indexes related to organic carbon of rock are used for pyrolysis assays in the same manner as the hydrogen/carbon and oxygen/carbon atomic ratios were used for kerogen. They allow us to characterize the same three types of organic matter defined as types 1,2 and 3 (Figure 3). The hydrogen index is expressed in milligrams of hydrocarbon compounds related to a gram of organic carbon, and the oxygen index in milligrams of carbon dioxide related to a gram of organic carbon. There is a correlation between the temperature of the maximum hydrocarbon production during pyrolysis (peak temperature) and the evolution stages of the kerogen. The $400^{\circ}-440^{\circ} \mathrm{C}$ range of peak temperatures corresponds to immature kerogen, the $440^{\circ}-460^{\circ} \mathrm{C}$ range corresponds to the main zone of oil genesis and to the main gas zone (or cracking zone) up to $460^{\circ} \mathrm{C}$.

The maximum hydrocarbon production during pyrolysis was reached for all the samples at low temperatures between $430^{\circ} \mathrm{C}$ and $434^{\circ} \mathrm{C}$ - the latter in the most deeply buried sample. The samples are thus immature with regard to oil genesis.

In all the studied samples, the hydrogen index is very low (less than 80 ) and the oxygen index ranges between 80 to 200 (Table 2). The oxygen-hydrogen diagram (Figure 3) shows that all the samples fall in the type 3 category, which indicates relatively higher contents of plant detritus and humic matter from a continental source. That type of organic matter, if matured, would yield preferentially gaseous hydrocarbons. The very low hydrogen index can be caused by a low content of pyrolysable organic matter diluted by large amounts of detrital material devoid of any pyrolysis potential. 


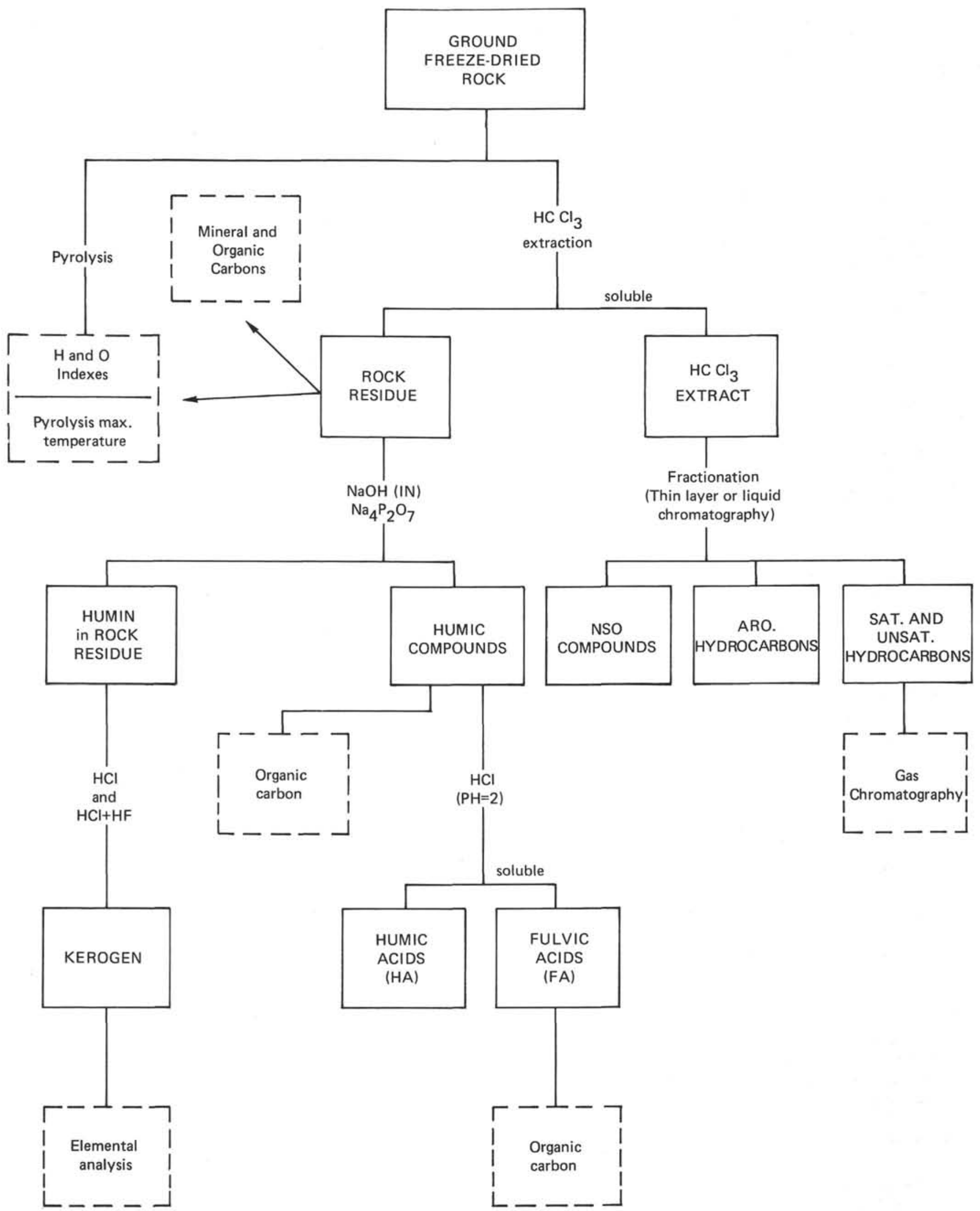

Figure 2. Schematic presentation of analytical processes. 
TABLE 2

Pyrolysis Assays for Samples From Site 391

\begin{tabular}{|c|c|c|c|c|c|}
\hline $\begin{array}{c}\text { Sample } \\
\text { Interval in cm }\end{array}$ & $\begin{array}{l}\text { Below } \\
\text { Sea } \\
\text { Floor } \\
(\mathrm{m})\end{array}$ & $\begin{array}{l}\text { Organic } \\
\text { Carbon } \\
\text { (\% weight) }\end{array}$ & $\begin{array}{l}\text { Hydrogen } \\
\text { Index } \\
\text { (mg. hydroc. } \\
\text { compounds/ } \\
\text { g. org. carb.) }\end{array}$ & $\begin{array}{c}\text { Oxygen } \\
\text { Index } \\
\text { (mg. } \mathrm{CO}_{2} / \\
\text { g. org. carb.) }\end{array}$ & $\begin{array}{c}\text { Pyrolysis } \\
\text { Temperature } \\
\left.\text { ( }{ }^{\circ} \mathrm{C}\right)\end{array}$ \\
\hline \multicolumn{6}{|l|}{ Hole 391A } \\
\hline $21-4,125-130$ & 655 & 0.37 & 31 & 151 & \\
\hline \multicolumn{6}{|l|}{ Hole 391C } \\
\hline $\begin{array}{r}6-3,145-150 \\
7-2,136-142 \\
8-2,145-150 \\
9-3,145-150 \\
10-3,145-150 \\
11-2,145-150 \\
12-4,120-125\end{array}$ & $\begin{array}{l}690 \\
730 \\
785 \\
842 \\
905 \\
925 \\
959\end{array}$ & $\begin{array}{l}0.70 \\
1.33 \\
1.13 \\
1.57 \\
2.72 \\
0.89 \\
1.77\end{array}$ & $\begin{array}{l}34 \\
19 \\
15 \\
39 \\
79 \\
52 \\
48\end{array}$ & $\begin{array}{r}80 \\
84 \\
93 \\
85 \\
122 \\
198 \\
98\end{array}$ & $\begin{array}{l}430 \\
430 \\
430 \\
430 \\
430 \\
430 \\
434\end{array}$ \\
\hline
\end{tabular}

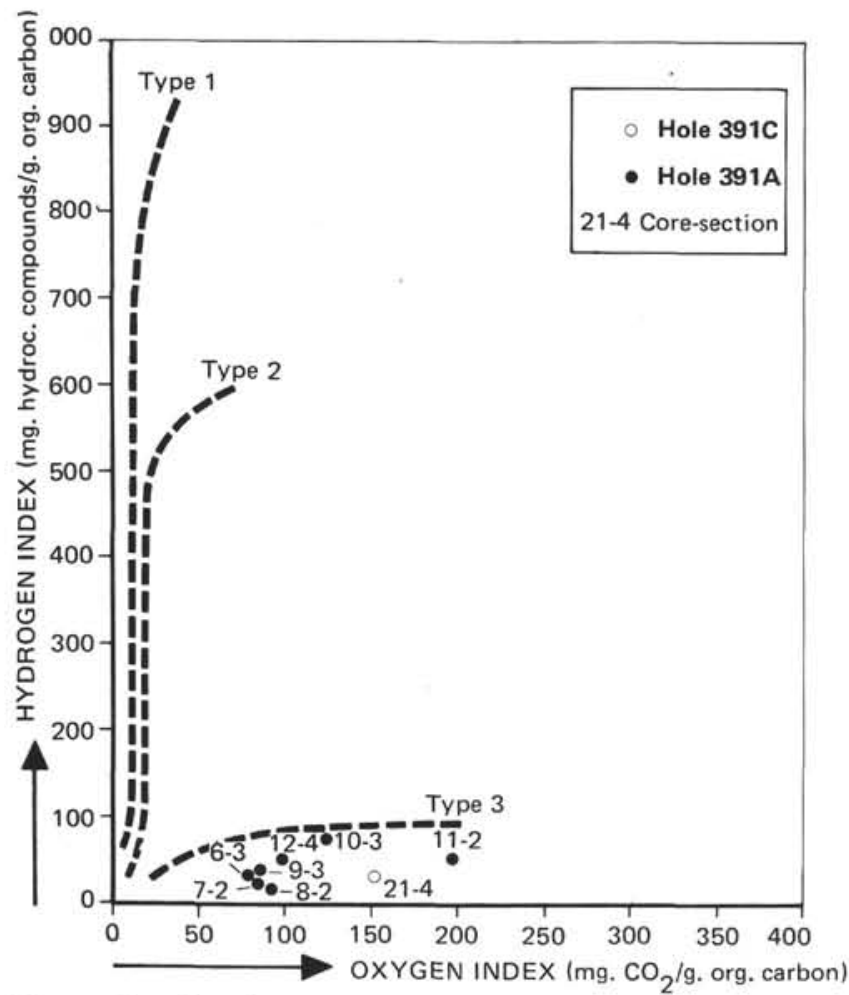

Figure 3. Pyrolysis assays. Hydrogen and oxygen indexes (data versus organic carbon content).

\section{Study of Chloroformic Extracts (Table 3, Figure 4)}

All samples (Table 3) had low contents of chloroformic extract (11 to $90 \mathrm{mg}$ ), except for Sample $391 \mathrm{C}-12-4,120-125 \mathrm{~cm}$. This sample yielded more chloroformic extract, but it was unfractionable by the usual thin-layer chromatography method. The extract to organic carbon ratio is generally low ( 0.01 to 0.02 and 0.04 ) and the non-soluble organic (NSO) compounds (Figure 4) comprise most of the samples $(71 \%, 84 \%$ to $92 \%)$.

The low content of extracts, related to predominantly heteroatomic compounds, generally indicates an immature material. There is a saturated fraction in the hydrocarbons larger than the aromatics. The gas chromatography analysis of the saturated fraction
TABLE 3

Chloroformic Extracts (after Site 391 Report, this volume) for Samples From Site 391

\begin{tabular}{|c|c|c|c|c|c|c|c|}
\hline \multirow[b]{3}{*}{$\begin{array}{c}\text { Sample } \\
\text { Interval in } \mathrm{cm}\end{array}$} & \multirow{3}{*}{$\begin{array}{c}\text { Depth } \\
\text { Below } \\
\text { Sea } \\
\text { Floor } \\
(\mathrm{m})\end{array}$} & \multirow{3}{*}{$\begin{array}{c}\text { HCCe3 } \\
\text { Extract } \\
\text { (weight } \\
\text { mg) }\end{array}$} & \multirow{3}{*}{$\begin{array}{c}\text { Extract/ } \\
\text { Rock } \\
\text { (weight } \\
\% \text { ) }\end{array}$} & \multirow{3}{*}{$\begin{array}{c}\text { Extract/ } \\
\text { Org. } \\
\text { Carbon } \\
\text { (weight) }\end{array}$} & \multicolumn{3}{|c|}{$\begin{array}{c}\text { Thin Layer } \\
\text { Chromatography }\end{array}$} \\
\hline & & & & & \multirow{2}{*}{$\begin{array}{l}\text { NSO } \\
\text { Com- } \\
\text { pounds } \\
(\%)\end{array}$} & \multicolumn{2}{|c|}{$\begin{array}{l}\text { Hydroc. } \\
\text { Fractions }\end{array}$} \\
\hline & & & & & & $\begin{array}{l}\text { Aro. } \\
(\%)\end{array}$ & $\begin{array}{l}\text { Sat. } \\
(\%)\end{array}$ \\
\hline \multicolumn{8}{|l|}{ Hole $391 \mathrm{~A}$} \\
\hline $21-4,125-130$ & 655 & 11.4 & 0.008 & 0.028 & 71 & 10 & 19 \\
\hline \multicolumn{8}{|l|}{ Hole 391C } \\
\hline $\begin{array}{r}6-3,145-150 \\
7-2,136-142 \\
8-2,145-150 \\
9-3,145-150 \\
10-3,145-150 \\
11-2,145-150\end{array}$ & $\begin{array}{l}690 \\
730 \\
785 \\
842 \\
905 \\
925\end{array}$ & $\begin{array}{l}28.4 \\
25.2 \\
21.1 \\
34.2 \\
90.5 \\
56.1\end{array}$ & $\begin{array}{l}0.013 \\
0.015 \\
0.014 \\
0.020 \\
0.043 \\
0.024\end{array}$ & $\begin{array}{l}0.018 \\
0.012 \\
0.012 \\
0.013 \\
0.015 \\
0.026\end{array}$ & $\begin{array}{l}87 \\
89 \\
88 \\
84 \\
90 \\
92\end{array}$ & $\begin{array}{l}5 \\
4 \\
3 \\
4 \\
5 \\
4\end{array}$ & $\begin{array}{r}8 \\
7 \\
9 \\
12 \\
5 \\
4\end{array}$ \\
\hline $12-4,120-125$ & 959 & 447.6 & 0.332 & 0.160 & \multicolumn{3}{|c|}{ no fraction } \\
\hline
\end{tabular}

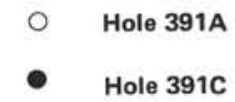

21-4 Core-section
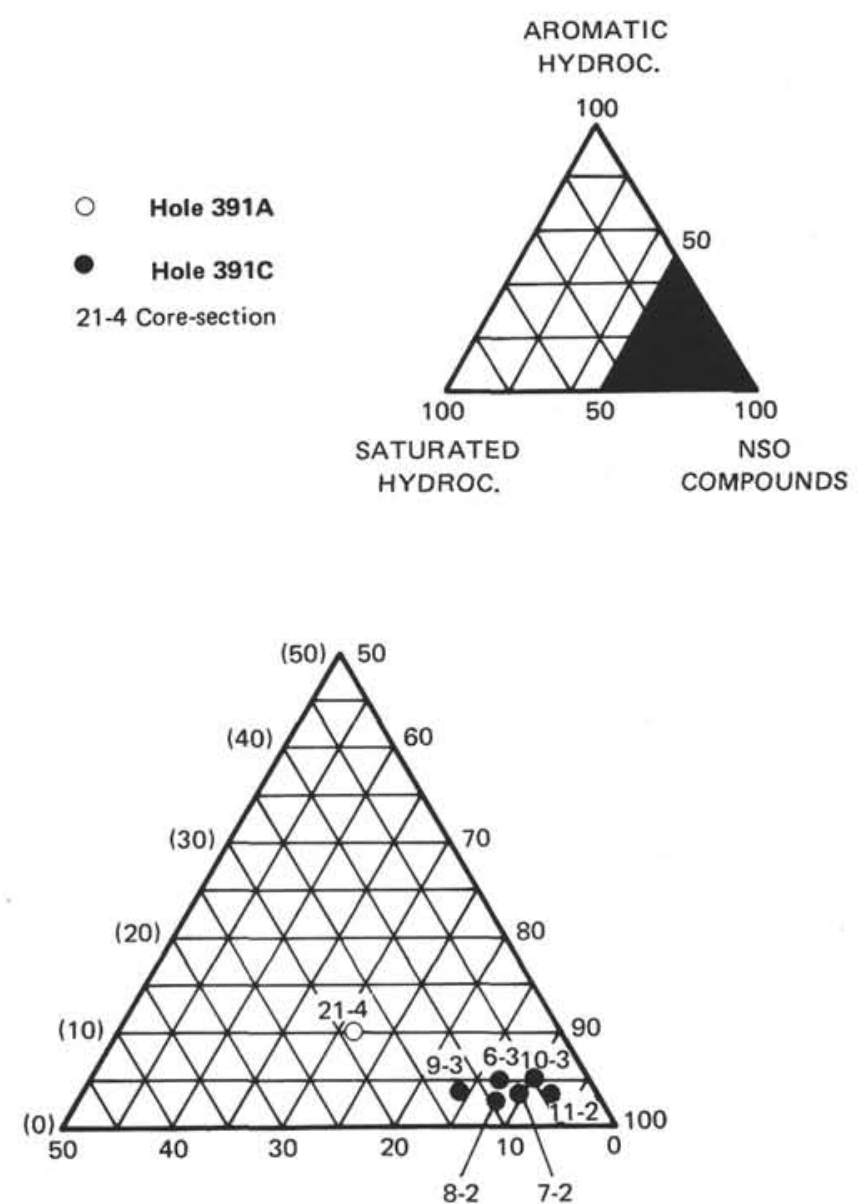

Figure 4. Gross composition of the chloroformic extracts.

reveals a normal alkanes distribution with an odd carbon number predominance in the $\mathrm{C}_{25}-\mathrm{C}_{29}$ range (Figure 5). The large proportion of $\mathrm{C}_{25}+$ odd normal alkanes suggests an important contribution of higher plants waxes.

${ }^{1}$ That study was performed by P. Albrecht and M. Dastillung, Institut de Chimie, Strasbourg (France). 
Hole 391C

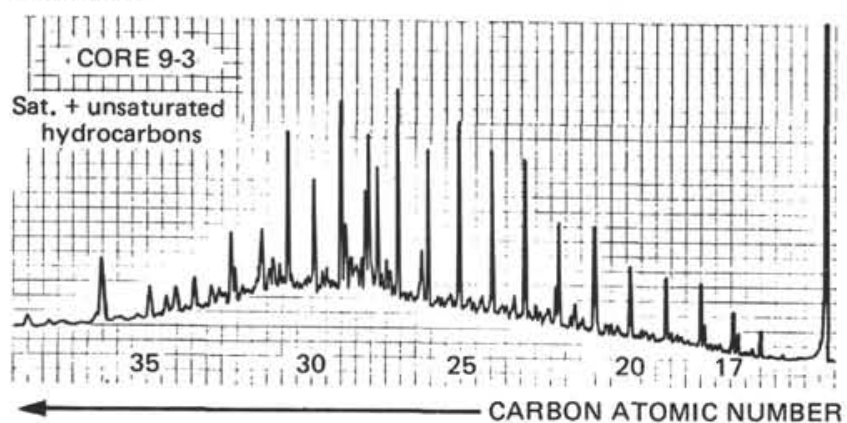

Figure 5. Extracts. Gas chromatography of saturated fraction.

Some polycyclic saturated hydrocarbons were investigated by computerized GC-MS ${ }^{1}$ in a composite sample comprising the saturates from the Upper Cretaceous Samples 391A-21-4, 125-130 cm to 391A-8$2,145-150 \mathrm{~cm}$. The mass chromatograms registered from masses 191, 217, and 231 are shown on Figure 6. They correspond, respectively, to the hopane, steranes, and methylsteranes series.

Steranes and methylsteranes were sparse to be analyzed, but triterpanes of the hopane type could be identified (Figure 6); the compounds belong to hopane series $([17 \beta \mathrm{H}, 21 \beta \mathrm{H}]$ hopane and $[17 \alpha \mathrm{H}, 21 \beta \mathrm{H}]$ hopane). The more stable $(17 \alpha \mathrm{H}, 21 \beta \mathrm{H})$ hopane series occurred in large quantities which indicates that the sediments are in a relatively advanced stage in early diagenesis.

\section{Study of Humic Compounds}

The eight samples were analyzed to determine per cent and ratios of the humic compounds (Table 4). The four samples of Upper Cretaceous sediments (391A-214 , 125-130 cm; 391C-6-3, 145-150 cm; 391C-7-2, 136$142 \mathrm{~cm} ; 391 \mathrm{C}-8-2,145-150 \mathrm{~cm}$ ) had a relatively high humic material content ( $\geq 30 \%$ of total organic carbon) as found in continental material at an immature stage of evolution. The relative content decreased in the upper Aptian-lower Albian (391C-9-3, 145-150 cm and $391 \mathrm{C}-10-3,145-150 \mathrm{~cm}$ samples $(11 \%$ and $15 \%)$. It reached 33 per cent in the Aptian Sample 391C-11-2, $145-150 \mathrm{~cm}$ and 13 per cent in the deepest sample, $391 \mathrm{C}-12-4,120-125 \mathrm{~cm}$, of supposed Aptian age. The abundance of humic compounds in sediments buried to $600-1000$ meters below the sea floor indicates that they contain a significant contribution of land-derived organic matter (Huc and Durand, 1977).

\section{Study of Kerogen}

The elemental composition of the kerogen fraction ${ }^{2}$ of the eight samples studied (Table 5) allows us to define the organic matter (Tissot et al., 1974) by plotting the hydrogen/carbon and oxygen/carbon atomic ratios on a Van Krevelen diagram (Figure 7).

The three Upper Cretaceous samples (391C-6-3, -7-2, $-8-2$ ) have the lowest hydrogen/carbon ration. They fall just below the other kerogen samples, 391C-9-3, -10-3, $11-2,-12-4$, which lie close to reference path III. That location suggests that the kerogen was derived from a continental source higher plants as previously deduced from pyrolysis assays on whole samples. The position of the four deepest samples (391C-9-3 to 12-4) on path III suggests that their stage of diagenesis is close to that of the main period of oil formation.

\section{CONCLUSIONS}

Despite a relatively high content of organic carbon, the Cretaceous clays cored at Site 391 are notgeochemically speaking sapropelic black shale.

From pyrolysis assays the major fraction of their organic matter is probably detrital and derived from continental higher plants. The study of kerogen and humic compounds confirms that the organic matter is of continental origin and has not yet reached the main phase of oil genesis.

${ }^{2}$ The proportion of unexplained ashes was so large (43\%) in Sample $391-\mathrm{C}-12-4,120-125 \mathrm{~cm}$, that its elemental analysis was insignificant.

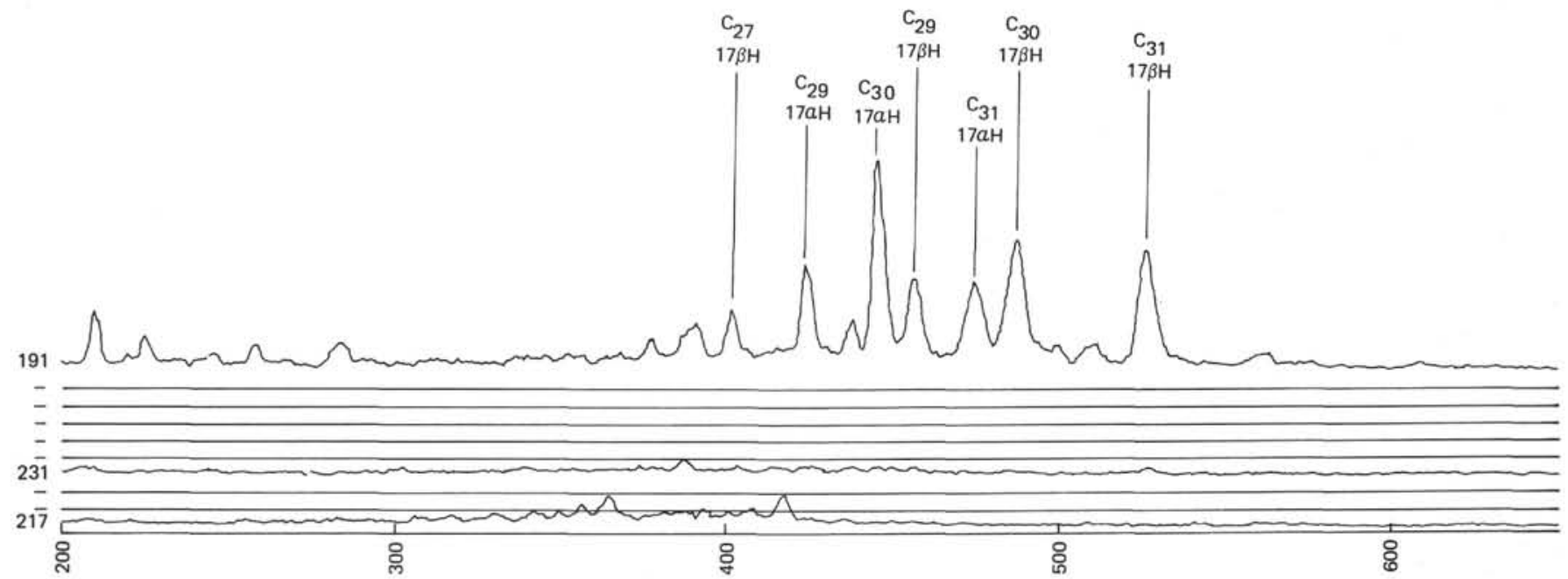

Figure 6. Mass chromatogram of saturated fraction for composite $291 \mathrm{~A}-21-4,125-130 \mathrm{~cm} ; 391 \mathrm{C}-6-3,145-150 \mathrm{~cm} ; 391 \mathrm{C}-7-2$, $136-142 \mathrm{~cm} ; 391 \mathrm{C}-8-2,145-150 \mathrm{~cm}$; samples corresponding to peaks 191, 217, and 231. 
TABLE 4

Total Organic and Per Cent Humic Compounds of Samples From Site 391

\begin{tabular}{|c|c|c|c|c|c|c|}
\hline \multirow[b]{2}{*}{$\begin{array}{c}\text { Sample } \\
\text { (Interval in } \mathrm{cm} \text { ) }\end{array}$} & \multirow{2}{*}{$\begin{array}{l}\text { Depth } \\
\text { Below } \\
\text { Sea } \\
\text { Floor } \\
(\mathrm{m})\end{array}$} & \multirow{2}{*}{$\begin{array}{l}\text { Total } \\
\text { org. } \\
\text { Carbon } \\
\text { (weight } \\
\% \text { ) }\end{array}$} & \multicolumn{3}{|c|}{$\begin{array}{c}\text { Carbon content } \\
\text { (\% of total org. carbon) }\end{array}$} & \multirow[b]{2}{*}{$\mathrm{FA} / \mathrm{HA}$} \\
\hline & & & $\begin{array}{c}\text { Humic } \\
\text { Compounds } \\
(\mathrm{FA}+\mathrm{HA})\end{array}$ & $\begin{array}{l}\text { Fulvic } \\
\text { Acids } \\
\text { (FA) }\end{array}$ & $\begin{array}{l}\text { Humic } \\
\text { Acids } \\
\text { (HA) }\end{array}$ & \\
\hline Hole 391A & & & & & & \\
\hline $21-4,125-130$ & 655 & 0.37 & 30.0 & 22.7 & 7.3 & 3.11 \\
\hline \multicolumn{7}{|l|}{ Hole 391C } \\
\hline $6-3,145-150$ & 690 & 0.70 & 67.1 & 5.7 & 61.4 & 0.09 \\
\hline $7-2,136-142$ & 730 & 1.33 & 31.6 & 2.5 & 29.1 & 0.08 \\
\hline $8-2,145-150$ & 785 & 1.13 & 38.0 & 3.6 & 34.4 & 0.10 \\
\hline $9-3,145-150$ & 842 & 1.57 & 10.8 & 3.4 & 7.4 & 0.45 \\
\hline $10-3,145-150$ & 905 & 2.72 & 14.8 & 2.7 & 12.7 & 0.16 \\
\hline $11-2,145-150$ & 925 & 0.89 & 33.7 & 3.9 & 29.8 & 0.13 \\
\hline $12-4,120-125$ & 959 & 1.77 & 13.6 & 3.2 & 10.4 & 0.30 \\
\hline
\end{tabular}

TABLE 5

Elemental Composition and Ash Content of Kerogens From Site 391 Samples

\begin{tabular}{|c|c|c|c|c|c|c|c|c|c|}
\hline \multirow[b]{2}{*}{ (Interval in $\mathrm{cm}$ ) } & \multirow{2}{*}{$\begin{array}{l}\text { Depth } \\
\text { Below } \\
\text { Sea } \\
\text { Floot } \\
\text { (m) }\end{array}$} & \multicolumn{5}{|c|}{ Weight $\%$, on Ash-Free Basis } & \multicolumn{2}{|c|}{ Atomic } & \multirow{2}{*}{$\begin{array}{c}\text { Ash } \\
\text { (weight } \\
\text { \%) }\end{array}$} \\
\hline & & C & H & o & s & $\mathrm{N}$ & $\mathrm{H} / \mathrm{C}$ & $\times 10^{2}$ & \\
\hline \multicolumn{10}{|l|}{ Hole 391A } \\
\hline $21-4,125-130$ & 655 & 48.75 & 3.64 & 28.12 & 16.26 & 3.24 & 0.89 & 43.25 & 52.22 \\
\hline \multicolumn{10}{|l|}{ Hole $391 \mathrm{C}$} \\
\hline $6-3,145-150$ & 690 & 65.58 & 3.97 & 22.14 & 5.41 & 2.90 & 0.73 & 25.33 & 46.84 \\
\hline $7-2,136-142$ & 730 & 63.08 & 3.75 & 21.76 & 9.43 & 1.98 & 0.71 & 25.88 & 35.73 \\
\hline $8-2,145-150$ & 785 & 73.72 & 3.37 & 18.89 & 1.84 & 2.17 & 0.55 & 19.22 & 22.63 \\
\hline $9-3,145-150$ & 842 & 66.64 & 4.29 & 21.12 & 5.56 & 2.39 & 0.77 & 23.77 & 31.56 \\
\hline $10-3,145-150$ & 905 & 69.83 & 4.87 & 20.78 & 1.74 & 2.78 & 0.84 & 22.32 & 30.78 \\
\hline $11-2,145-150$ & 925 & 73.09 & 4.66 & 15.52 & 4.37 & 2.35 & 0.77 & 15.93 & 33.22 \\
\hline $12-4,120-125$ & 959 & 68.98 & 4.47 & 20.25 & 3.57 & 2.72 & 0.78 & 22.02 & 32.60 \\
\hline
\end{tabular}

\section{ACKNOWLEDGEMENTS}

The authors are indebted to Dr. J. Hunt of Woods Hole Oceanographic Institute for his comments and reviewing the present paper.

\section{REFERENCES}

Durand, B. and Espitalie, J. 1973. Etude de la matiere organique au cours de l'enfouissement des sédiments: C.R. Acad. Sci., Paris. v. D 276, p. 2253-2256.

Durand, B., Espitalie, J., Nicaise, G., and Combaz, A., 1972. Etude de la matière organique insoluble (kérogène) des argiles du Toarcien du Bassin de Paris. Première partieEtude par les procédés optiques. Analyse élémentaire. Espitalie, J., Durand, B., Roussel, J.C., and Souron, C., 1973. Etude de la matière organique insoluble (kérogène) des

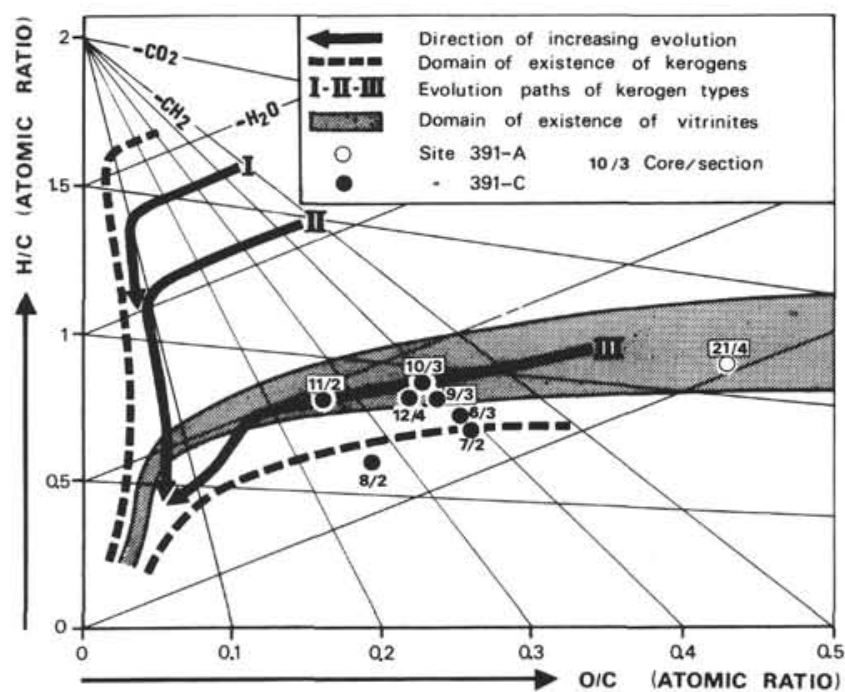

Figure 7. Kerogens. $\mathrm{H} / \mathrm{C}$ and $\mathrm{O} / \mathrm{C}$ diagram.

argiles du Toarcien du Bassin de Paris. II - Etudes en spectrométrie infrarouge, en analyse thermique différentielle et en analyse thermogravimétrique: Rev. Inst. Franc. Pétrole, v. 28, p. 37-66.

Espitalie, J., Laporte, L.J., Madec, M., Marquis, F., Leplat, P., Paulet, J., Boutefeu, A., 1977. Methode rapide de caracterisation des roches mères, de leur potential petrolier et de leur degré d'evolution. Rev., Inst. Franc. Pétrole, v. 32 p. $32-42$.

Huc, A.Y. and Durand, B., 1977. Occurrence and significance of humic acids in ancient sediments, Fuel, v. 56, January, p. 73-80.

Huc, A.Y., Durand, B., and Monin, J.C., 1978. Humic compounds and kerogens in cores from Black Sea sediments Leg 42B, Sites 379A, B, and 380A. In Ross, D.A., and Neprochnov, Y.P., et al., Initial Reports of the Deep Sea Drilling Project, Volume 42, Part 2: Washington (U.S. Government Printing Office).

Huc, A. Y., Roucache, J., Bernon, M., Caillet, G., and Da Silva, M., 1976. Application de la chromatographie sur couche mince à l'étude quantitative et qualitative des extraits de roche et des huiles. Rev. Inst. Franc. Pétrole, v 31, p. 67-98.

Robin, P. L., Rouxhet, P.G., and Durand, B., in press. Caractérisation des kérogènes et de leur évolution par spectroscopie infra-rouge: Advances in Org. Geochemistry, Madrid 1975.

Tissot, B., Durand, B., Espitalie, J., and Combaz, A., 1974. Influence of the nature and diagenesis of organic matter in the formation of petroleum: Am. Assoc. Petrol Geol. Bull., v. 58 , p. $499-506$. 